\title{
Traditional Wisdom and Potential of Community Conserved Areas of Jhalawar District, Rajasthan, India
}

\author{
N. K. Rathore' ${ }^{1}$ P. S. Chauhan ${ }^{2}$ and V. K. Yadav ${ }^{3 *}$ \\ ${ }^{1}$ Department of Botany, Government P. G. College, Jhalawar (Rajastahan), India \\ ${ }^{2}$ Department of Forest Biology and Tree Improvement, College of Horticulture and Forestry, \\ Jhalrapatan, Jhalawar, Agriculture University, Kota, India \\ ${ }^{3}$ Department of Forestry, Mewar University, Gangrar, Chittorgarh (Rajasthan), India \\ *Corresponding author
}

\section{A B S T R A C T}

\section{Keywords}

Community, habitat, Jhalawar, Sacred grove, Tradition

Article Info

Accepted:

20 December 2020

Available Online:

10 January 2021
The protection of nature for religious purpose is an ancient practice, many communities follow the practice of selling aside certain patches of natural vegetation as Community Conserved Areas (CCAs) or sacred grove where community norms prevent cutting of certain tree species in a light protect biodiversity through their cultural, spiritual values. Local communities play important role in protecting these plant and other elements of nature through their ethnic, social and religious practices. These ensure the survival of the grove in its original conditions. The sacred grove is an indicator and benchmark of nature that might have existed in the particular region. It is a natural laboratory, a habitat island, a gene bank and a store house of important rare and threatened plant species. The Survey was conducted in certain urban and tribal dominated area of Jhalawar district. The climate of Jhalawar district is on the whole fairy dry and healthy is one of the rainiest parts of the state of Rajasthan. The Jhalawar ecoregion is habited by Meena, Kanjar, Banjara, Bheel, Sahariya and other tribal communities and it is diversified in terms of traditional culture of its indigenous tribal communities. Diversity also prevails in plant communities used by them. This traditional culture has notable impact on the society. Total 32 sacred places and 26 tree species in Jhalawar district including temple, baories, raries and orans have been identified and surveyed. Their administration management and ecological feature along with tree species (more than 200 year) kept protected and conserved were incorporated in this study. Paper suggests what challenges do community conserved areas are facing and study of traditional culture, their threats and factors responsible for biodiversity depletion.

\section{Introduction}

Human relationship with nature from time immemorial is exposed either through massive exploitation of natural resources for the advantage of the mankind, or conservation and maintenance of natural resources through cultural and religious beliefs. These traditional methods of conservation can be seen in sacred groves which are usually surrounding forest patches in tribal areas and protected by local tribal communities for 
religious purpose; they often prohibit felling of trees and poaching of wild fauna, though in some cases do allow the collection of firewood, fodder, and medicinal plants by local people for their own use (Hughes and Chandran 1998). Local communities in rural and tribal areas follow the practice of setting aside certain patches of natural vegetation as scared grove "dedicated to deity of village God". The hills and plains in different mosaic forest of study area dotted with numerous sacred groves under different names of their folk God and Goddess.

The sacred groves are found all over the India, manages by local community in different size, composition, including burial grounds (Mgumia and Oba 2003; Wadley and Colfer 2004) and sites of ancestral or deity worship with different forms of gesture (Ramakrishnan et al., 1998). These are the storehouse of rare and endemic species and can be regarded as the remnant of the primary forest left untouched by the local communities and protected by them with thinking that the deities reside in these places. The credit goes to Prof. Madhav Gadgil's group for reviving interest in the dormant field from the Indian institute in Bangalore were encouraged by the discovery of an ancient grove in the Western Ghats (Gadgil and Vartak 1976).

Several community conserved areas or sacred groves are still conserved for their importance and they contain a diverse gene pool of ethnobotanically important species. At the international level, these places are now being recognized as indigenous reserves, biocultural heritage sites and community reserves. Collectively they are referred to as "community conserved areas".

The main objectives of this study were enlisting, evaluating recognition status and management of CCAs. Discuss the historic roots and role that human and plant relationship have had in managing nature and environment related to CCAs. What challenges do CCAs are facing and study of traditional culture, their threats and factors responsible for biodiversity depletion?

\section{Materials and Methods}

\section{Study area}

The district Jhalawar lies in the South-East corner of Rajasthan at the edge of the Malwa plateau between $23^{\circ} 45^{\prime} 20^{\prime \prime} \mathrm{N}$ to $24^{\circ} 52^{\prime} 17^{\prime \prime} \mathrm{N}$ latitudes and $75^{\circ} 27^{\prime} 35^{\prime \prime} \mathrm{E}$ to $76^{\circ} 56^{\prime} 48^{\prime \prime} \mathrm{E}$ longitudes (Fig. 1). Nearly $87 \%$ forest area is under subsidiary edaphic type of dry tropical forest and Northern tropical dry deciduous mixed forests. It is one of the rainiest parts of the Rajasthan state where the average annual rainfall is 35 " which keeps it cool and gentle breezes ward off the stifling humidity.

Preliminary surveys were made for collection of the primary information. Sacred groves or CCAs were intensively surveyed for the tree composition. Information like species of the plants, age of the tree or any monument, diameter, height and their ethnobotanical use which were used by local communities. Questionnaire surveys were followed for the collection of the sociological information. The information recorded from the field were compiled and arranged for further study. So, to know the nature of the community conserved areas or forest, 32 sacred groves were recorded from the Jhalawar district. Trees species were identified based on the available literature (Hooker, 1872-1897). The information on historical background, traditions, rituals, cultures, taboos, possible threats were collected from tribal communities through personal communication and community interaction through semi-structured questionnaire(Manna et al., 2017). 


\section{Results and Discussion}

Total 32 sacred place in Jhalawar district including temple, baories, raries and orans, have been identified and surveyed. Overall, 26 tree species were recorded from all sacred places from the Jhalawar district (Fig. 2). It has been observed that each sacred place is associated with a local deity of temple or monastery of both. Brahmani Mata Temple (Khanpur), Bodh Math and Mata Temple (Banniya in Bagher), Mitthe Saheb Dargah (Gagron Fort), Pipa Ji Dham (Gagron), Sati Mata Chabutra Golan (Khanpur), Rata Devi Temple (Asnawar), Kamkheda Balaji Temple (Aklera), Eid Gah, (Jhalawar), Naulakha Fort (Balaji Temple), Nasiya Ji Baori, Thakur Shab Bauri, Dwarika Dhish Temple (Jhalrapatan) are well known religious places (Table 1). People of rural and tribal areas worship folk God and Goddess namely Ghans Bheru ji (Bheru Ji Chabutra), Sheetla Mata Ji, Hiraman Ji, Jorawar Singh Ji, Bheru Ji, Bala Ji, Takha Ji, Bapu Ji, Dev Narayan Ji, Utt Ji, Pachadmal Ji, Kanwar Ji, Khichi Baba, Kalla Ji, Hardol Ji, Ragtya Bheru Ji, Gawalya Bheru Ji, Maha Dev Ji, Shetrapal Ji, Bhomya Ji, Bhesarji, Ramapir Ji, Metthe Baba, Bijasan Mata Ji, Choth Mata Ji, Sajya. It is observed that sacred places have been protected by rural people, dedicated to "deity of village God" (folk God and Goddess), and protecting nature and vegetation is habitual practice of tribal communities. Their beliefs, customs, myths, ritualistic, ceremonies, associated with plants and nature.

They elaborate rituals with which people surrender themselves to the numerous fairs and festivals prove the love for joyous celebrations. A variety of festivals were held in the district as a part of the celebrations of various religious groups, major of them were Holi, Dashehara, Deepawali, Gowardhan Puja (Worship of cows), Janmastami, Rakhi, Ied Millan, Basant Panchmi, Ganesh Chaturthi, along with folk Tejaji Fair (Tejaji Chabutra), Sawani Amavasya, Makar Sakranti, Teez, Dhol Akadashi are also releted to these religious places (Table2). The beliefs and superstitions have been deep rooted in rural and tribal areas of Jhalawar. Certain customs and beliefs have been added into the tradition in the name of religious ritual. So, one of the practices to wear the rosaries made out of Ocimum sanctum (Tulsi) by those who worship lord "Vishnu". Similarly, those who worship lord "Shiva" wear the beads of Elaeocarpus genitures or E. sphaericus seed rosaries.

There are several rare and threatened plant species that enjoy the protection through traditional rituals associated with community conserved areas mainly Schrebera swietenioides (Mokha), Pandanus odoratissimus (Kewara), Crateva adansonii (Barna), Syzygium cumini(Jamun), Cratea nurvala (Chhotabarna), Bridelia retusa, Acacia pinnata (Kumta), Capparis spinosa (Kalwari), Salvadora oleoides (Peelu), Anogeissus latifolia (Safed Dhonkda), Sterculia villosa (Udal) and Boswellia serrata (Salar) were recorded. Local communities play important role in protecting these plant and other elements of nature through their ethnic, social and religious practices.Their administration management and ecological feature along with tree species (more than 200 year) kept protected and conserved are mentioned in (Table 1).It is also observed that some tree species mainly Ficus benghalensis, Ficus racemosa, Ficus religiosa, Azadirachta indica, Tamarindus indicus, Madhuca indica, Aegle marmelos have been in practice in almost all visited sacred places.

The study highlights the role of local communities in conservation as well as restoration of degraded sacred groves. Even simple protection measures with local awareness would help in protecting fragments 
of natural vegetation. There are several rare plants species that enjoy the protection through community conserved areas (sacred groves, orans, Baories, Raries, Temple). Similarly, the Gond tribal community of Mendha (Lekha) village in Gadchiroli district, of Maharashtra has protected 1,800 ha of forest. This village has also generated selfemployment and assured income for all members throughout the year (Pathak and Gour-Broome 2001). Inter-relationship of human and nature from time immemorial is expressed either through massive exploitation of natural resources for the benefit of the mankind, or conservation and management of natural resources through religious and cultural beliefs. This traditional conservation system can be best viewed in sacred groves which are usually forest patches of village surroundings and which protected by local communities for religious purpose. Local communities in rural and tribal area follow the practice of setting aside certain patches of natural vegetation as scared grove "dedicated to deity of village God". The hills and plains in different mosaic forest of study area dotted with numerous sacred groves under different names of their folk God and Goddess.

Table.1 Sacred groves and existing tree species (more than 200 years) of study area of Jhalawar district

\begin{tabular}{|c|c|c|c|c|}
\hline $\begin{array}{l}\text { S. } \\
\text { No. }\end{array}$ & $\begin{array}{l}\text { Name of } \\
\text { Village }\end{array}$ & Name of Place & Foundation & Tree Species \\
\hline 1. & Jhirnia & Shiv Temple & 250 years con & $\begin{array}{l}\text { Anogeissus pendula, Anogeissus latifolia, } \\
\text { Butea monosperma, Ficus benghalensis, Ficus } \\
\text { religiosa, Tamarindus indica, Terminalia } \\
\text { bellerica, Aegle marmelos }\end{array}$ \\
\hline 2. & Unnel & Baori & Ancient* & $\begin{array}{l}\text { Diospyros melanoxylon, Ficus benghalensis, } \\
\text { Ficus religiosa, Tectona grandis, Azadirachta } \\
\text { indica }\end{array}$ \\
\hline 3. & Raipur & Nani Baori & Ancient & $\begin{array}{l}\text { Terminalia bellerica, Terminalia arjuna, } \\
\text { Butea monosperma, Ficus benghalensis }\end{array}$ \\
\hline 4. & Khanpur & $\begin{array}{l}\text { Brahmani Mata } \\
\text { Temple }\end{array}$ & Ancient* & $\begin{array}{l}\text { Madhuca indica,Diospyros melanoxylon, } \\
\text { Acacia nilotica }\end{array}$ \\
\hline 5. & Bagher & $\begin{array}{l}\text { Baori and } \\
\text { Amjhar Mata } \\
\text { Temple }\end{array}$ & Ancient** & $\begin{array}{l}\text { Sterculia urens, Anogeissus latifolia, Wrightia } \\
\text { tomentosa, Aegle marmelos, Balanites } \\
\text { aegyptiaca, Feronia limonia, Schleichera } \\
\text { oleosa, Butea monosperma, Crateva } \\
\text { adansonii,Boswellia serrata }\end{array}$ \\
\hline 6. & $\begin{array}{l}\text { Banniya } \\
\text { (Bagher) }\end{array}$ & $\begin{array}{l}\text { Bodha Math and } \\
\text { Mata Temple }\end{array}$ & Ancient** & $\begin{array}{l}\text { Azadirachta indica, Butea monosperma, } \\
\text { Sterculia urens, Anogeissus latifolia, Wrightia } \\
\text { tomentosa, Madhuca indica, Ficus religiosa }\end{array}$ \\
\hline 7. & $\begin{array}{l}\text { Gagraon } \\
\text { Fort }\end{array}$ & $\begin{array}{l}\text { Mitthe Saheb } \\
\text { Dargah }\end{array}$ & 600 years con & $\begin{array}{l}\text { Butea monosperma, Sterculia urens, } \\
\text { Anogeissus latifolia, Wrightia tomentosa, } \\
\text { Madhuca indica, Ficus religiosa, Tamarindus } \\
\text { indica, Azadirachta indica }\end{array}$ \\
\hline 8. & $\begin{array}{l}\text { Jhalawar } \\
\text { (Gagron) }\end{array}$ & Pipa Ji Dham & 500 years con & $\begin{array}{l}\text { Ficus benghalensis, Ficus religiosa, } \\
\text { Azadirachta indica, Holoptelea intergifolia, } \\
\text { Wrightia tomentosa }\end{array}$ \\
\hline 9. & $\begin{array}{l}\text { Golan } \\
\text { (Khanpur) }\end{array}$ & $\begin{array}{l}\text { Sati Mata } \\
\text { Chabutra }\end{array}$ & 300 years & $\begin{array}{l}\text { Ficus benghalensis, Tamarindus indica, } \\
\text { Azadirachta indica }\end{array}$ \\
\hline
\end{tabular}




\begin{tabular}{|c|c|c|c|c|}
\hline 10. & Asnawar & $\begin{array}{l}\text { Rata Devi } \\
\text { Temple }\end{array}$ & Ancient* & $\begin{array}{l}\text { Anogeissus pendula, Diospyros melanoxylon, } \\
\text { Holoptelea intergifolia, Azadirachta indica, } \\
\text { Wrightia tomentosa, Mitragyna parviflora }\end{array}$ \\
\hline 11. & Aklera & $\begin{array}{l}\text { Sheetala Mata } \\
\text { Temple }\end{array}$ & Ancient & Mitragyna parviflora, Azadirachta indica \\
\hline 12. & Aklera & $\begin{array}{l}\text { Kamkheda } \\
\text { Balaji Temple }\end{array}$ & Ancient con & $\begin{array}{l}\text { Ficus benghalensis, Ficus religiosa, Holoptelea } \\
\text { intergifolia }\end{array}$ \\
\hline 13. & Jhalawar & $\begin{array}{l}\text { Raj Rajeshwar } \\
\text { Temple }\end{array}$ & 150 years con & $\begin{array}{l}\text { Azadirachta indica, Ficus benghalensis, } \\
\text { Ficus religiosa }\end{array}$ \\
\hline 14. & Jhalawar & $\begin{array}{l}\text { Ganesh Temple } \\
\text { (Garh Place) }\end{array}$ & 300 years con & Azadirachta indica, Ficus benghalensis \\
\hline 15. & Jhalawar & Sati Chabutra & 500 years con & $\begin{array}{l}\text { Feronia limonia, Ficus benghalensis,Butea } \\
\text { monosperma, Azadirachta indica }\end{array}$ \\
\hline 16. & Jhalawar & Durga Temple & 300 years con & $\begin{array}{l}\text { Ficus benghalensis, Azadirachta indica, Ficus } \\
\text { religiosa }\end{array}$ \\
\hline 17. & Jhalawar & $\begin{array}{l}\text { Panch Mukhi } \\
\text { Balaji }\end{array}$ & 150 years con & $\begin{array}{l}\text { Ficus benghalensis, Butea monosperma, } \\
\text { Azadirachta indica }\end{array}$ \\
\hline 18. & Jhalawar & Eid Gah & 200 years con & Tamarindus indica, Azadirachta indica \\
\hline 19. & Jhalawar & $\begin{array}{l}\text { Tambain ki } \\
\text { Khan (Teez ka } \\
\text { Chabutra) }\end{array}$ & 200 years** & $\begin{array}{l}\text { Diospyros melanoxylon, Azadirachta indica, } \\
\text { Acacia nilotica, Ficus benghalensis }\end{array}$ \\
\hline 20. & Jhalawar & $\begin{array}{l}\text { Mangal Nath } \\
\text { Dungri }\end{array}$ & 500 years** & $\begin{array}{l}\text { Madhuca indica, Butea monosperma, } \\
\text { Mangifera indica, Tamarindus indica, Ficus } \\
\text { benghalensis }\end{array}$ \\
\hline 21. & Jhalrapatan & $\begin{array}{l}\text { Naulakha Fort } \\
\text { (Balaji, Shiv } \\
\text { Temple) }\end{array}$ & 300 years con & $\begin{array}{l}\text { Madhuca indica, Ficus benghalensis, } \\
\text { Ficus religiosa, Azadirachta indica }\end{array}$ \\
\hline 22. & Jhalrapatan & Nasiya Ji Baori & 400 years con & $\begin{array}{l}\text { Holoptelea intergifolia, Mangifera indica, } \\
\text { Syzygium cumini, Tectona grandis }\end{array}$ \\
\hline 23. & Jhalrapatan & $\begin{array}{l}\text { Nasiya Jain } \\
\text { Temple }\end{array}$ & 400 years con & Ficus benghalensis, Azadirachta indica \\
\hline 24. & Jhalrapatan & $\begin{array}{l}\text { Thakur Sahab } \\
\text { Baori }\end{array}$ & 300 years con & $\begin{array}{l}\text { Mimusops elengi, Ficus benghalensis, } \\
\text { Ficus religiosa, Azadirachta indica }\end{array}$ \\
\hline 25. & Jhalrapatan & $\begin{array}{l}\text { Duwarika Dhish } \\
\text { Temple }\end{array}$ & 300 years con & $\begin{array}{l}\text { Ficus benghalensis, Azadirachta indica Ficus } \\
\text { religiosa,Holoptelea intergifolia }\end{array}$ \\
\hline 26. & Jhalrapatan & $\begin{array}{l}\text { Gopi Nath } \\
\text { Temple }\end{array}$ & 250 years con & $\begin{array}{l}\text { Ficus benghalensis, Ficus religiosa, } \\
\text { Holoptelea intergifolia }\end{array}$ \\
\hline 27. & Jhalrapatan & $\begin{array}{l}\text { Shanti Nath Jain } \\
\text { Temple }\end{array}$ & 400 years con & Ficus benghalensis, Azadirachta indica \\
\hline 28. & Jhalrapatan & $\begin{array}{l}\text { Thandi Jhiri } \\
\text { (Shiv Temple) }\end{array}$ & Ancient con & $\begin{array}{l}\text { Mimusops elengi, Ficus benghalensis, } \\
\text { Ficus religiosa, Azadirachta indica } \\
\text { Holoptelea intergifolia, Mangifera indica, } \\
\text { Syzygium cumini, Tectona grandis }\end{array}$ \\
\hline 29. & Jhalrapatan & $\begin{array}{l}\text { Chandra Bhaga } \\
\text { (Shiv Temple) }\end{array}$ & Ancient con & $\begin{array}{l}\text { Ficus benghalensis, Ficus religiosa, } \\
\text { Azadirachta indica, Mangifera indica, } \\
\text { Syzygium cumini, Tectona grandis }\end{array}$ \\
\hline 30. & $\begin{array}{l}\text { Tin Dhar } \\
\text { (J.Patan) }\end{array}$ & Banjarni Temple & 300 years* & $\begin{array}{l}\text { Ficus benghalensis, Ficus religiosa, } \\
\text { Azadirachta indica, Butea monosperma, } \\
\text { Tectona grandis }\end{array}$ \\
\hline
\end{tabular}




\begin{tabular}{|r|l|l|l|l|}
\hline 31. & $\begin{array}{l}\text { Khandiya } \\
\text { Village }\end{array}$ & $\begin{array}{l}\text { Nath Ji Samadhi/ } \\
\text { Chabutra }\end{array}$ & Ancient & $\begin{array}{l}\text { Holoptelea intergifolia, Mangifera indica, } \\
\text { Syzygium cumini, Ficus benghalensis }\end{array}$ \\
\hline 32. & Gaori Pond & $\begin{array}{l}\text { Balaja Temple } \\
\text { and Mata Ji } \\
\text { Temple of } \\
\text { Tamboly } \\
\text { communities }\end{array}$ & 150 years con & $\begin{array}{l}\text { Holoptelea intergifolia, Mangifera indica, } \\
\text { Syzygium cumini, Tectona grandis, Azadirachta } \\
\text { indica }\end{array}$ \\
\hline
\end{tabular}

$(*)$ - Ignored, $(* *)$ - Degraded and decline, (con) - Conserved, $(* * *)$ under danger and unsafe

Table.2 Fair and Festivals of celebration by tribal communities of Jhalawar

\begin{tabular}{|c|c|c|c|c|}
\hline S.No. & Name of Village & Fair and Festivals & Foundation & Importance \\
\hline 1 & Kanwari & Ram Kund Fair & Ancient & Tribal fair \\
\hline 2 & Panwad & Shivratri Fair & Ancient & Related to Load Shiv \\
\hline 3 & Khanpur & Makar Sakranti Fair & 500 years & $\begin{array}{l}\text { Related to Makar } \\
\text { Sakranti }\end{array}$ \\
\hline 4 & Khanpur & Bangali Baba Fair & Ancient & $\begin{array}{l}\text { Related to Brahamani } \\
\text { Temple }\end{array}$ \\
\hline 5 & Mahua Khera & Teja Ji Fair & Ancient & $\begin{array}{l}\text { Related to Teja Ji and } \\
\text { Load Shiv }\end{array}$ \\
\hline 6 & Bareda & Bheru Ji Fair & 500 years & Related to Bheru Ji \\
\hline 7 & Gagraon Fort & $\begin{array}{l}\text { Mitthe Mahabali Fair } \\
\text { (urs) }\end{array}$ & 400 years & $\begin{array}{l}\text { Related to Mitthe } \\
\text { Mahabali Dargah }\end{array}$ \\
\hline 8 & $\begin{array}{l}\text { Bhanwarasa (Govind } \\
\text { Puriya) }\end{array}$ & Mata Ji Fair & Ancient & Related to Mata Temple \\
\hline 9 & Jhalawar & Teez (Tambe ki Khan) & Ancient & Related to Teez Gangaor \\
\hline 10 & $\begin{array}{l}\text { Jhalrapatan, Chandra } \\
\text { Bhaga }\end{array}$ & Kartik Fair, Sawan fair & Ancient & $\begin{array}{l}\text { Related to Chandra } \\
\text { Bhaga and Shiv Temple }\end{array}$ \\
\hline
\end{tabular}

Fig.1 Map of study area - Jhalawar district

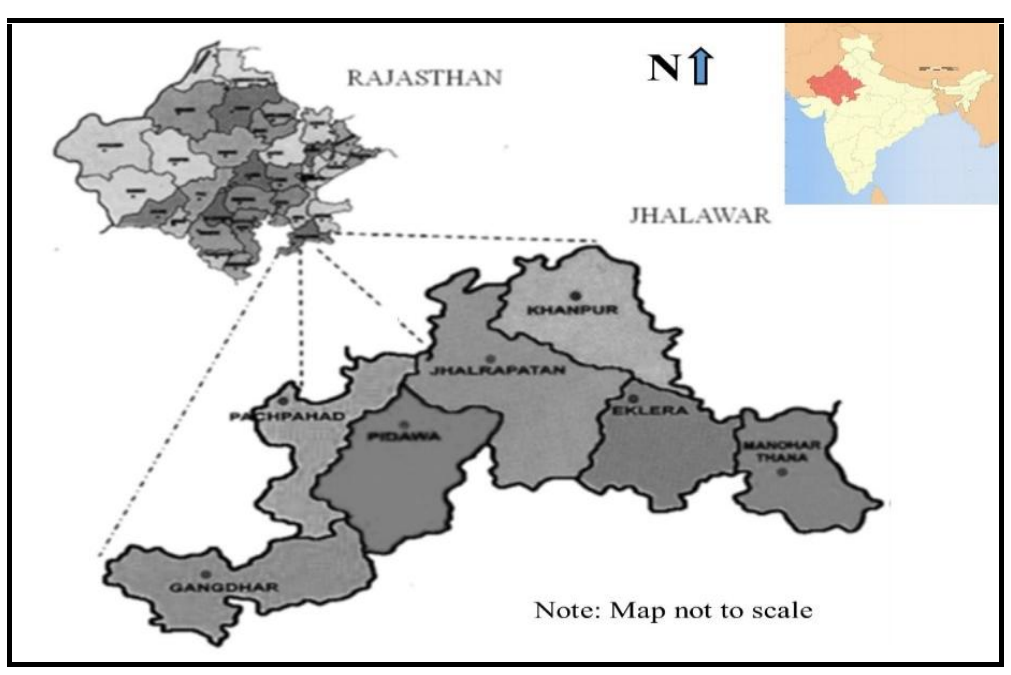


Fig.2 Dominance of tree species from study area

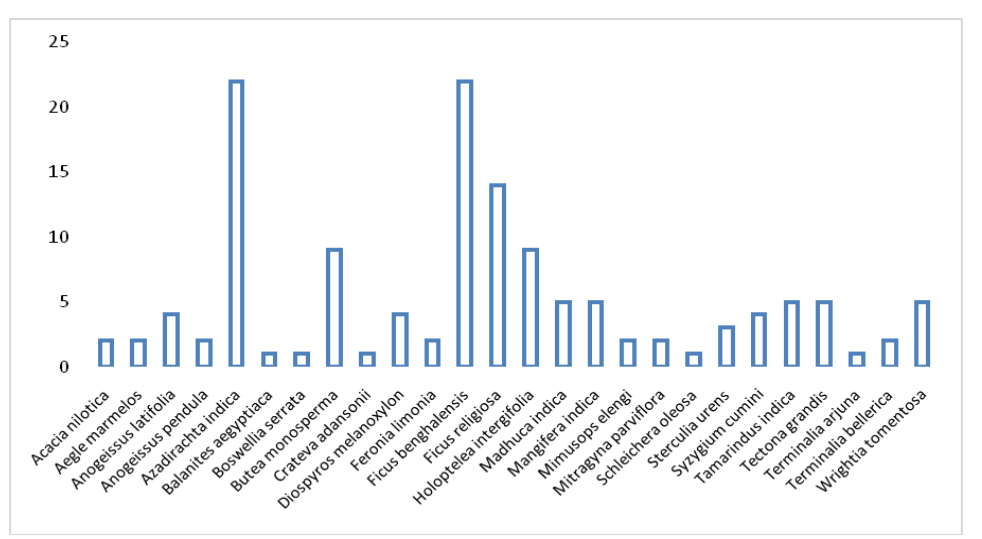

Study revealed a disturbing scenario of religious places and sign of human impact and consequent degradation are alarming in Bodha Math (Bager), Ganesh Temple of (Kakoni). Tambe ki Khan (Jhalawar), Mangal Nath Dungri (Jhalawar) on hill slop is ignored and degraded place need protection and conservation through ecorestoration while Thandi Jhiri (Jhalrapatan)Prithvi Villas Palace, Bijlia Bharak Area Sheetaleshwar Mahadeo Temple Chandrabhaga are seemingly well conserved.

Rata Devi Area (Jhalawar) facing very heavy biotic pressure of animals on the area due to regular heavy grazing,due to this original habit of Anogeissus pendula has been changed. Other sites mainly Hujoor ka Bagicha, Gokul puria Bagicha, Karonde ke balaji, Dhokde ke Balaji,Khejadi ke Balaji, Tambe ki Khan (Jhalawar) are seen totally exploited and found degraded under impact of urbanization; these are totally replaced by Kota stone polishing factories, residential colonies or by other man-made activities. Padmanabh Sun Temple, Jhalrapatan is totally converted in a crowded marketplace, which destroyed trees surrounding it.

There has been, in recent past, rising awareness on the history and importance of sacred groves. As a positive outcome of the rising conservation ethos, protecting with fence involving local people in the diverse landscape elements like agricultural field, plantation and human habitation. As community dynamics not only depends on the abiotic factors but also on the influence of associated species which have the capacity in modifying the community structure (Turkington et al., 1985 and Lobo et al., 2003) and as such, we can predict the range of extension of a previously prevailed forest area only through the study of similarities in species composition between existing forest patches on the scale of their physical distance from each other. Thandi Jhiri (Jhalrapatan), Prithvi Villas Palace, Bijlia Bharak Area Sheetaleshwar Mahadeo Temple, Chandrabhaga are found well under supervision of different community committees and Government organization. Several sacred groves or community conserved areas are still conserved and have importance in preserving a diverse gene pool of ethnobotanically important species. Sacred grove Thandi Jhiri (Jhalrapatan) is owned by forest department. Recently a variety of plant species are protected under in-situ conservation in Herbal garden of Thandi Jhiri (Jhalrapatan) of Jhalawar under supervision of forest department.

It has better growing conditions harbor rich natural plants along with old tree species (more than 200 years old) mainly Pandanus 
odoratissimus, Mangifera indica, Mimusops elengi, Ficus benghalensis, Ficus racemosa, Ficus religiosa, Azadirachta indica, Temarindus indicus, Syzygium cumini etc. Skeels which has been serving as key stone resources for survival of local fauna.Prithvi Villas Palace (Darbar ki Kothi) presently it is the private residence of the family of farmer ruler. It is full of natural vegetation along with old tree species (more than 200 years old) mainly Madhuca indica, Holarrhena antidysenterica, Ficus benghalensis, Pandanus odoratissimus, Grewia subinaequalis, Schrebera swietenioides, Sterculia urens, Mitragyna parviflora, Santalum album, Syzygium cumini, Madhuca indica, Mangifera indica, Schrebera swieteniodes, Schleichera oleosa, Dendrocalamus strictus, Santalum album and Bambusa spp.

Thandi Jhiri (Jhalrapatan), Prithvi Villas Palace can be considered as best example of protecting several wild plant species by local people for their spiritual values. These places also serve as gene pool with repository of rare and endemic species. These untouched and conserved sacred groves can be used as demonstration sites for study and research.

\section{Acknowledgement}

We thank to the Forests Department of Jhalawar, Government of Rajasthan (India), for giving permission and help rendered by the Range Officers of Jhalawar Forest Department to carry out this study. We also thank to local community or people of Jhalawar district for their valuable comments in questionnaire survey.

\section{References}

Gadgil, M. and Vartak, V.D. 1976. Sacred groves of western ghat of India. Economical Botany, 30: 152-160
Hooker, J.D. 1872-1897. Flora of British India. L. Reeve, London.

Hughes, J.D. and Chandran, M.D.S. 1998. Sacred groves around the earth: an overview. In: Ramakrishnan, P.S., Saxena, K.G. and Chandrashekara, U.M. (Eds). Conserving the sacred for biodiversity management. New Delhi, India: Oxford and India Book House.

Lobo, J.A., Quesada, M., Stoner, M.E., Fuchs, E.J., Herrerias-Diego, Y., Rojas, J. and Saborio, G. 2003. Factors affecting phenological patterns of Bombacaceous trees in seasonal forest in Costa Rica and Mexico. American Journal of Botany, 90: 1054-1063.

Manna, S., Manna, S., Ghora, T.K. and Roy., A. 2017. Sacred grove as remnant forest: A vegetation analysis. Biodiversitas, 18 (3): 899-908.

DOI:

10.13057/biodiv/d180306

Mgumia, F.H. and Oba, G. 2003. Potential role of sacred groves in biodiversity conservation in Tanzania. Environmental Conservation,30 (3): 259-265.

Pathak, N. and Gour-Broome, V. 2001. Tribal Self-Rule and Natural Resource Management: Community-based Conservation at Mendha-Lekha, Maharashtra, India. Kalpavriksh, Pune and IIED, London.

Ramakrishnan, P.S., Saxena, K.G. and Chandrashekara, U.M. 1998. Conserving the sacred for biodiversity management. Oxford and India Book House, New Delhi, India.

Turkington, R., Harpar, J.L., De Jong, P. and Aarssen, L.W. 1985. A reanalysis of inter-specific association in an old pasture. Journal of Ecology, 73: 123131.

Wadley, R.L. and Colfer, C.J.P. 2004. Sacred forest, hunting, and conservation in West Kalimantan, Indonesia. Human Ecology, 32: 313-338. 
How to cite this article:

Rathore, N. K., P. S. Chauhan and Yadav, V. K. 2021. Traditional Wisdom and Potential of Community Conserved Areas of Jhalawar District, Rajasthan, India. Int.J.Curr.Microbiol.App.Sci. 10(01): 3203-3211. doi: https://doi.org/10.20546/ijcmas.2021.1001.373 